УДК 342.9

DOI https://doi.org/10.32849/2663-5313/2020.3.42

Олексій Дрозд,

докт. юрид. наук, дочент,

начальник відділу докторантури та ад’юнктури

Національної академї внутрішніх справ

\title{
ПРИНЦИПИ ОРГАНІЗАЦІЇ ТА ДІЯЛЬНОСТІ ДЕРЖАВНОГО БЮРО РОЗСЛІДУВАНЬ
}

Констатується, що діяльність Державного бюро розслідувань, як і будь-якого іншого державного органу, має здійснюватися в суворій відповідності з певними принципами, які відображають його призначення, впливають на визначення його завдань, иілей і повноважень, є підгрунтям для формування його системи та структури. Досліджується зміст, сутність і иільова спрямованість принципів функиіонування Державного бюро розслідувань, які відображають як загальнотеоретичні погляди на ию правову категорію, так і характерні особливості роботи й організачї зазначеного правоохоронного органу. Також визначається роль наведених приниипів у характеристиці адміністративно-правового статусу ивого органу. З'ясовуються особливості правового закріплення системи приниипів Державного бюро розслідувань у чинному законодавстві, а також специфіка їх прояву у правозастосовній діяльності. Аналізується сутність $і$ зміст таких основних засад організаиії та діяльності Державного бюро розслідувань, як верховенство права, законність, справедливість, неупередженість, незалежність і персональна відповідальність кожного працівника Державного бюро розслідувань, відкритість та прозорість діяльності Державного бюро розслідувань для суспільства й демократичного цивільного контролю, підзвітність і підконтрольність визначеним законом державним органам, політична нейтральність та позапартійність його прачівників, єдиноначальність у реалізаиї повноважень Державного бюро розслідувань. Визначаються недоліки нормативного врегулювання основних засад діяльності Державного бюро розслідувань, а також обгрунтовується висновок про необхідність деталізаиї закріплення їх змісту, оскільки законодавець окреслює систему основних засад організачії й діяльності Державного бюро розслідувань лише в загальних рисах $і$ не розкриває повною мірою їх зміст та особливості реалізаиї.

Ключові слова: верховенство права, відкритість, Державне бюро розслідувань, єдиноначальність, законність, незалежність, неупередженість, підзвітність, підконтрольність, політична нейтральність, позапартійність, принципи, прозорість, справедливість.

Постановка проблеми. Організація та діяльність Державного бюро розслідувань (далі - ДБР), як і будь-якого іншого державного органу, має здійснюватись у суворій відповідності до певних принципів, тобто науково розроблених та апробованих практикою керівних ідей, основоположних засад, вихідних положень, орієнтирів, які спрямовані на досягнення оптимальних і стабільних результатів його діяльності, а також забезпечують ї̈ ефективність.

Принципи не можуть існувати самі по собі. Оскільки принципи зумовлені метою та цільовою спрямованістю функціонування ДБР, вони відображають його призначення і саму сутність функціонування; впливають на визначення його завдань і функцій; $\epsilon$ підгрунтям для формування його системи та організаційної структури тощо. Як об'єктивно зумовлені нормативні начала організації та діяльності ДБР, принципи знаходять своє нормативне закріплення в Законі України «Про Державне бюро розслідувань» (далі - Закон) у вигляді керівних вимог та критеріїв поведінки, на які спираються усі інші правові приписи та яким мають відповідати усі без винятку юридично значущі дії працівників ДБР.

3 огляду на таку важливу роль і фундаментальне значення принципів організації та діяльності ДБР, їх дослідження займає пріоритетне місце в процесі характеристики адміністративно-правового статусу цього правоохоронного органу. Адже принципи не лише становлять свого роду «фундамент», основу функціонування ДБР, але й слугують тим критерієм, який дозволяє визначити ефективність виконання покладених на нього завдань і функцій, визначити недоліки його функціонування, розробити оптимальні шляхи ї усунення та вдосконалення його діяльності.

Мета статті. Враховуючи викладене вище, основною метою даної наукової статті $€$ визначення сутності та змісту основних 
принципів функціонування ДБР, які відображають як загальнотеоретичні погляди на дану правову категорію, так і характерні особливості організації й діяльності Державного бюро розслідувань, його специфічну цільову спрямованість та особливе місце в національній правоохоронній системі.

Виклад основного матеріалу. Принципи діяльності будь-якого органу не існують самі по собі. Усі вони у своїй сукупності утворюють цілісну внутрішньо організовану систему, яка складається із взаємопов'язаних між собою елементів, що узгоджені за метою та спрямовані на реалізацію спільних завдань і функцій.

ДБР не $є$ винятком із зазначеного правила. Натепер система основних принципів його організації та діяльності закріплена в ст. 3 Закону і включає в себе такі елементи (принципи): 1) верховенство права; 2) законність; 3) справедливість; 4) неупередженість; 5) незалежність і персональна відповідальність кожного працівника ДБР; 6) відкритість та прозорість діяльності ДБР для суспільства та демократичного цивільного контролю, підзвітність і підконтрольність визначеним законом державним органам; 7) політична нейтральність і позапартійність; 8) єдиноначальність у реалізації повноважень ДБР [1]. Оскільки кожен із зазначених елементів розкриває окрему сторону функціонування ДБР, пропонуємо проаналізувати їх більш детально.

Принщип верховенства права. У сучасних умовах демократичних перетворень принцип верховенства права визнається одним iз фундаментальних та водночас найбільш багатогранним загально-правовим принципом функціонування органів державної влади загалом та правоохоронних органів зокрема.

Принцип верховенства права - один із небагатьох принципів організації та діяльності ДБР, який дістав своє офіційне закріплення в Конституції України. Зокрема, він згадується у ст. 8 Основного закону держави. Водночас сам факт конституційного закріплення принципу верховенства права дав підстави деяким науковцям висловити сумніви з приводу доцільності його дублювання в Законі. Так, наприклад, О. В. Біденко зазначає: «Враховуючи той факт, що Конституція в Україні має найвищу юридичну силу, а усі інші закони приймаються на їі основі та повинні їй відповідати, потреби у такому дублюванні немає» [2, с. 90]. У цілому 3 таким підходом можна було би погодитись. Однак, враховуючи той факт, що ст. 8 Конституції України не дає визначення верховенства права, а лише закріплює положення, згідно з яким в Україні визнається і діє цей принцип, виникає необхідність у його додатковому законодавчому врегулюванні.

То який же зміст вкладає законодавець у принцип верховенства права? Відповідь на це питання можна отримати, якщо більш детально проаналізувати пункт 1 ч. 1 ст. 3 Закону. Зокрема, у ньому зазначається, що відповідно до принципу верховенства права «людина, іï життя і здоров'я, честь і гідність, недоторканність і безпека визнаються найвищою соціальною цінністю, а права і свободи людини та їх гарантії визначають зміст і спрямованість діяльності держави» [1].

Детально проаналізувавши зміст наведеної законодавчої норми, ми дійшли висновку, що вона неповною міріою розкриває зміст принципу верховенства права. Зокрема, як нам вдалося з'ясувати, в судовій практиці даний принцип тлумачиться значно ширше. Для прикладу можна навести рішення КСУ від 02.11.2004 р., у якому зазначається, що «одним 3 проявів верховенства права $є$ те, що право не обмежується лише законодавством як однією з його форм, а включає й інші соціальні регулятори, зокрема норми моралі, традиції, звичаї тощо, які легітимовані суспільством і зумовлені історично досягнутим культурним рівнем суспільства» [3]. Викладене означає, що «право» не можна розглядати лише як «закон» чи «систему правових норм». Право насамперед є втіленням справедливості. Якщо екстраполювати даний висновок на сферу функціонування ДБР, то з упевненістю можна стверджувати, що принцип верховенства права вимагає від усіх працівників ДБР діяти справедливо та неупереджено.

Водночас навіть таке розуміння принципу верховенства права повною мірою не розкриває усі його грані. Якщо його трактувати більш широко, що останніми роками стало панівним в юридичній літературі, даний принцип визначається як «сукупність засад, положень, ідей, що грунтуються на природних правах особи та її індивідуальній автономності від держави». До речі, саме таке розуміння змісту принципу верховенства права можна зустріти в рішеннях Європейського суду з прав людини, який, розглядаючи справи, керується європейською Конвенцією про захист прав людини та основних свобод 1950 року. У преамбулі до цього документа зазначається, що принцип верховенства права і є тією фундаментальною засадою, яка об’єднує країни-учасниці Ради Свропи.

Таким чином, підсумовуючи викладене, можна стверджувати, що принцип верховенства права дає можливість працівникам ДБР 
творчо підходити до застосування закону і враховувати вимоги інших соціальних регуляторів. Однак вказане положення в жодному разі не може служити для бездумного застосування закону, різного роду зловживань, а також несправедливого обмеження прав та свобод громадян.

Приниип законності. Положення принципу законності є логічним продовженням принципу верховенства права і в найбільш загальному розумінні означає обов'язок працівників ДБР діяти на підставі та в межах закону, з урахуванням його цілей та в установленому ним порядку.

Так само, як і принцип верховенства права, принцип законності дістав своє закріплення в Конституції України. Зокрема, йому присвячено ч. 2 ст. 19 Основного Закону, згідно 3 якою органи державної влади та органи місцевого самоврядування їх посадові особи зобов'язані діяти лише на підставі, в межах повноважень та у спосіб, що передбачені Конституцією та законами України. Водночас, на відміну від принципу верховенства права, зміст принципу законності в ст. 3 Закону не розкривається. Однак якщо проаналізувати інші його положення, то можна дійти висновку, що принцип законності в діяльності ДБР проявляється у вигляді двох взаємопов'язаних елементів: по-перше, працівники ДБР мають діяти в суворій відповідності до вимог закону; по-друге, працівники ДБР зобов'язані вживати заходів для забезпечення виконання закону іншими суб'єктами права.

Аналізуючи принцип законності діяльності ДБР, необхідно обов'язково згадати i про такий його складник, як система нормативно-правових актів та ii ієрархічна побудова. Так, у разі встановлення невідповідності положень нормативно-правового акта вимогам Конституції України, закону України, міжнародному договору, згода на обов'язковість якого надана ВРУ, або ж іншому нормативно-правовому акту, працівник ДБР повинен застосовувати той нормативно-правовий акт, який має вищу юридичну силу. При цьому, згідно 3 ч. 3 ст. 8 Конституції України, найвищу юридичну силу має Конституція України, норми якої мають пряму дію. Друге місце в ієрархічній системі нормативно-правових актів посідають міжнародні договори, згода на обов'язковість яких надана ВРУ; третє закони; четверте - підзаконні нормативноправові акти.

Окрім проаналізованих нами вище положень, зміст принципу законності організації та діяльності ДБР проявляється в таких моментах: 1) працівники ДБР повинні діяти виключно в межах наданих їм повноважень, дотримуватись передбаченого законом порядку і термінів здійснення процесуальних дій, а також процедури їх юридичного оформлення; 2) працівники ДБР не можуть виконувати злочинні чи явно незаконні розпорядження та накази; за виконання таких розпоряджень і наказів вони можуть бути притягнуті до встановленої законом відповідальності; 3) необхідність виконання наказів, розпоряджень, доручень, вказівок тощо, а також політична, економічна, службова чи інша доцільність не можуть бути підставою для порушення працівником ДБР вимог принципу законності; 4) працівникам ДБР заборонено незаконно втручатись у діяльність інших суб'єктів права, а останнім гарантується право оскарження їхніх незаконних дій та рішень; 5) порушення працівниками ДБР законів чи інших нормативно-правових актів під час виконання покладених на них повноважень спричиняє визнання вчинених дій і прийнятих на їх основі рішень незаконними; 6) організація та діяльність ДБР мають бути чітко врегульовані, прозорими, а також відкритими для контролю з боку як уповноважених контролюючих і наглядових суб'єктів, так і громадськості.

Приниип справедливості - це ще один фундаментальний принцип організації та діяльності ДБР. У найбільш загальному розумінні він визначається як «міра морально-правової домірності вкладеного та отриманого в усіх сферах життєдіяльності людини та їхнього правового забезпечення <..>; вимога відповідності між практичною роллю різних індивідів (соціальних груп) у житті суспільства та їхнім соціальним становищем, між їхніми правами та обов'язками, злочином і покаранням, заслугами людей та їхнім суспільним визнанням» [4, с. 224]. 3 викладеного випливає, що зазвичай справедливість розглядається як одна із властивостей права, яка, серед іншого, виражається в рівному юридичному масштабі поведінки, а також у пропорційності відповідальності вчиненому правопорушенню.

У діяльності ДБР принцип справедливості цілком обгрунтовано набуває соціального відтінку. Зокрема, він передбачає, що працівники ДБР під час реалізації покладених на них повноважень мають діяти об'єктивно, безсторонньо, враховувати думку усіх учасників, відкидаючи особисті інтереси та зацікавленість. Більше того, вони мають бути високоморальними та неупередженими, мати високі професійні якості та бездоганну репутацію.

Варто зауважити, що Конституція України не містить прямої згадки про принцип 
справедливості, що, однак, не применшує його ролі та значення. Зокрема, дослівний аналіз інших положень Основного закону дозволяє стверджувати, що принцип справедливості тісно пов'язаний, випливає і переплітається з іншими правовими засадами діяльності ДБР. Насамперед, як ми уже зазначали вище, він пов'язаний із принципом верховенства права, який зобов'язує усіх працівників ДБР «діяти справедливо та неупереджено», використовуючи в правозастосвчій діяльності не лише правові норми, але й інші соціальні регулятори. Також він тісно переплітається із принципом законності, який передбачає, що всі закони апріорі мають бути справедливими і правовими. Принцип справедливості тісно пов'язаний із принципом формальної рівності, який зобов'язує працівників ДБР діяти неупереджено, однаково ставитись до всіх учасників правовідносин, незалежно від їхньої статі, раси, національності, кольору шкіри, віросповідання, світогляду, політичної належності та інших ознак.

Особливу роль та значення принцип справедливості набуває в ситуаціях, коли виникає необхідність усунення прогалин або ж суперечностей в законодавстві. Адже, як відомо, до застосування аналогії права обов'язково висуваються не лише вимоги розумності та добросовісності, але й справедливості. У даному випадку справедливість $€$ критерієм чесного вирішення справи, ідеалом, до якого треба прагнути та яким потрібно керуватися одночасно із законом.

Принци неупередженості тісно пов'язаний із принципом справедливості і навіть інколи ототожнюється із ним, що зумовлено змістовою єдністю понять, які використовуються для їх позначення. Так, наприклад, один із найбільш відомих тлумачних словників С. I. Ожегова «неупередженість» визначає як «відсутність необ'єктивності до будь-якого процесу, явища; справедливість» [5, с. 42]. Також неупередженість досить часто використовується як синонім таких понять, як «об'єктивність», «безпристрасність», «безсторонність», «незацікавленість» тощо. Досить ємне трактування неупередженості сформулював у своєму дисертаційному дослідженні Д. А. Гаврилов. Зокрема, під неупередженістю особи він пропонує розуміти «ії внутрішню свободу від упередженості, здатність здійснювати самоконтроль, формулювати й долати сумніви, пов'язані з необхідністю уникнення односторонності в оцінці обставин справи [6, с. 127].

Якщо екстраполювати таке загальне розуміння неупередженості на сферу функціонування ДБР, то можна зробити висновок, що реалізація принципу неупередженості організації та діяльності ДБР означає відсутність суб'єктивної зацікавленості працівників ДБР в результатах своєї роботи; їх інтереси ані прямо, ані опосередковано не повинні бути пов'язані зі службовими інтересами; під час виконання своїх посадових обов'язків вони повинні уникати виникнення ситуацій потенційного чи реального конфлікту інтересів, а також негайно повідомляти своїх безпосередніх керівників чи уповноважені органи про виникнення таких ситуацій; їхня поведінка під час виконання службових обов'язків має бути нейтральною, тобто вільною від стороннього впливу і тиску; вони не повинні керуватись власними емоціями та уподобаннями під час реалізації покладених на них повноважень; вони повинні утримуватись від вчинків і дій, які можуть викликати сумнів в їхній об'єктивності та незалежності; вони повинні негайно повідомляти своїх безпосередніх керівників чи уповноважені органи про будь-які факти вчинення щодо них незаконного впливу та тиску, підкупу чи іншого схиляння до прийняття необгрунтованих рішень; вони повинні уникати конфліктних та інших ситуацій, які можуть негативно позначитись на їхній особистій репутації, на репутації ДБР в цілому, а також підірвати їхній авторитет тощо.

Усе вищевикладене дозволяє нам визначити два основні аспекти реалізації принципу неупередженості в діяльності ДБР перший - об'єктивний, що передбачає відсутність будь-яких зовнішніх джерел впливу на працівників ДБР; другий - суб'єктивний, що передбачає їхню особисту безпристрасність, відсутність однобічності в оцінці фактів, а також незацікавленість у результатах розгляду справи. Відразу ж зауважимо, що запропонований нами поділ $€$ досить умовним, оскільки зазначені аспекти тісно пов'язані між собою, впливають один на одного, формують і наповнюють один одного.

Принцип незалежності і персональної відповідальності кожного працівника ДБР. Цей принцип перебуває у тісному зв'язку із попереднім принципом, оскільки сьогодні більшість науковців розглядає незалежність як одну із передумов об'єктивності та неупередженості діяльності посадових осіб.

На відміну від принципу неупередженості, зміст принципу незалежності значно ширше висвітлений в науковій літературі. Водночас вимушені констатувати, що більшість таких наукових досліджень присвячена аналізу суддівської незалежності, оскільки саме цей принцип натепер отримав своє конституційне закріплення. Що стосується принципу незалежності ДБР, то він має дещо 
вужчий зміст, однак це жодним чином не применшує його роль і значення в організації та діяльності ДБР. Основна цільова спрямованість даного принципу полягає у тому, щоб, з одного боку, убезпечити ДБР та його працівників від публічного тиску на них з боку вищих посадових осіб держави, політичних партій, представників інших правоохоронних органів тощо, не допустити випадків їх використання для вирішення спірних політичних питань та задоволення політичних чи особистих інтересів; а з іншого боку не допустити корупції, свавілля, безкарності, безконтрольності та безвідповідальності з боку працівників ДБР.

Аналіз чинного законодавства, а також практики діяльності ДБР дозволяє дійти висновку, що нині принцип незалежності ДБР включає в себе декілька вимог: спеціальний статус ДБР як самостійного і правоохоронного органу, що не належить до жодної з гілок влади, і, відповідно, особливий порядок визначення його системи, структури, порядку фінансування та організаційного забезпечення діяльності; самостійний характер діяльності працівників ДБР (вони самостійно приймають рішення, керуючись професійною правосвідомістю, і несуть за них персональну відповідальність); непов'язаність їхньої діяльності будьякими обставинами крім вимог закону; їхня незалежність від зовнішніх факторів, стороннього впливу та тиску; встановлення для них цілої низки обмежень особистісних, політичних та трудових прав (заборона належати до політичних партій, заборона щодо сумісництва та суміщення, заборона роботи близьких осіб тощо); підзвітність та підконтрольність ДБР тощо.

Характеристика змісту принципу незалежності ДБР буде неповною без аналізу гарантій забезпечення його реалізації. I хоча Закон не містить чіткого переліку гарантій незалежності ДБР, дослівний аналіз його змісту до таких гарантій дозволяє віднести: особливий порядок призначення на посаду та звільнення 3 посади директора ДБР та його заступників, а також інших працівників ДБР; встановлення граничних термінів перебування на посаді директора ДБР; закріплення вичерпного переліку підстав для звільнення з посади директора ДБР, а також інших працівників ДБР; заборона незаконного втручання в діяльність ДБР, а також будь-якого впливу чи тиску на його працівників; забезпечення особистої безпеки працівників ДБР та членів їхніх сімей, захист їхніх прав та професійних інтересів; встановлення особливого порядку притягнення до дисциплінарної відповідальності працівни- ків ДБР; забезпечення належного фінансування, матеріально-технічного, соціального та іншого забезпечення діяльності ДБР тощо.

Принцип відкритості та прозорості діяльності ДБР для суспільства та демократичного цивільного контролю, підзвітності та підконтрольності визначеним законом державним органам. Аналізоване положення ч. 1 ст. 3 Закону містить у собі відразу два принципи: по-перше, це відкритість і прозорість; по-друге, це підзвітність і підконтрольність. Однак, більш поглиблено аналізуючи, в межах зазначених принципів можна диференціювати й інші правові засади (наприклад, гласність, публічність).

Принцип відкритості та прозорості тісно пов'язаний 3 іншими засадами діяльності ДБР (насамперед із принципами справедливості, неупередженості та незалежності) й досить часто виступає як основна гарантія забезпечення їх реалізації. Також він є необхідною передумовою реалізації принципу підзвітності та підконтрольності, оскільки гарантує доступ до інформації про основні напрями та результати роботи ДБР.

3 огляду на специфіку завдань і функцій, які покладаються на ДБР, а також особливу сферу його повноважень, принцип відкритості та прозорості його діяльності набуває особливого значення. Річ у тім, що досить часто працівники ДБР документують злочини найвищих посадових осіб держави; здійснюють розслідування найбільш резонансних кримінальних проваджень; викривають корупційні схеми в найбільш важливих сферах суспільного життя. Тому існує підвищений інтерес громадськості, в тому числі міжнародної спільноти, до результатів його діяльності, прийнятих рішень та вжитих заходів.

У сучасних умовах, коли рівень довіри громадськості до правоохоронної системи перебуває на максимально низькій позначці за всю історію існування незалежної України, забезпечення реалізації принципу відкритості та прозорості діяльності ДБР $\epsilon$ ключовою умовою, яка здатна забезпечити нормальне функціонування цього новоствореного правоохоронного органу. Без відкритості та гласності про довіру до ДБР не може бути й мови. Розуміючи це, законодавець у п. 6 ч. 1 ст. 3 Закону намагається окреслити межі можливого обмеження даного принципу, зазначаючи, що «ДБР діє гласно тією мірою, що не порушує права і свободи людини і громадянина, не суперечить вимогам кримінального процесуального законодавства та законодавства про державну таємницю» [1]. 
Принцип політичної нейтральності ma nозапартіüності. Більшість науковців розглядають даний принцип як один зі складників принципу незалежності та неупередженості. У цілому такий підхід слід визнати цілком обгрунтованим, оскільки, як ми уже зазначали вище, будь-які особистісні переконання та погляди, в тому числі політичної спрямованості, жодним чином не можуть впливати на виконання працівниками ДБР покладених на них повноважень.

У найбільш загальному розумінні принцип політичної нейтральності та позапартійності зводиться до законодавчого закріплення лише двох заборон: по-перше, заборони використання ДБР у партійних, групових чи особистих інтересах; по-друге, заборони діяльності в ДБР політичних партій. Однак, як свідчать результати проведеного нами дослідження, окрім наведених, можна визначити ще декілька складників цього принципу: ДБР у своїй діяльності має бути незалежним від рішень, заяв чи позицій політичних партій та громадських об'єднань; працівники ДБР мають виконувати покладені на них повноваження незалежно від політичних переконань та партійної належності; в органах та підрозділах ДБР не може проводитись політична діяльність та політична агітація, так само працівники ДБР не можуть брати участь в політичній діяльності та проводити політичну агітацію; працівники ДБР не можуть висловлювати особисте ставлення до діяльності політичних партій під час виконання покладених на них повноважень, так само вони не можуть використовувати надані ім права 3 політичною метою.

Принцип єдиноначальності у реалізацї повноважень ДБР у поєднанні із принципом процесуальної самостійності слідчого органу ДБР. Це єдиний принцип ДБР, який 3 моменту створення цього органу зазнав кардинальних змін. Так, до 03.12.2019 р. даний принцип звучав так: «єдиноначальності у поєднанні з колективним способом реалізації окремих повноважень ДБР». Як бачимо, законодавець прийняв рішення суттєво обмежити зміст даного принципу і виключив із нього згадку про колегіальний спосіб реалізації окремих повноважень. На жаль, обмежений обсяг даної статті не дозволяє нам більш детально дослідити причини, передумови та можливі наслідки такого кроку, а тому нижче пропонуємо зосередити свою увагу лише на характеристиці змісту аналізованої засади.

До найбільш характерних ознак принципу єдиноначальності у реалізації повноважень ДБР можна віднести такі: здійснення управління діяльністю ДБР на основі єди- ноначального прийняття рішень директором ДБР, його контролю за процесом їх виконання, а також його повної відповідальності за результати діяльності ДБР; встановлення чіткої управлінської вертикалі із лінійною підпорядкованістю всіх органів і підрозділів ДБР його директору; обов'язковість для нижчестоящих органів і підрозділів ДБР рішень і вказівок, що надходять від вищестоящого органу та директора ДБР, їх точне та своєчасне виконання (з урахуванням вимог принципу законності); можливість директора ДБР одноособово змінити чи скасувати рішення, прийняті підпорядкованими йому працівниками (з урахуванням вимог принципу процесуальної самостійності слідчого органу ДБР) тощо. Однак, поряд із встановленням таких обмежень для органів і підрозділів ДБР, а також його працівників, реалізація даного принципу передбачає: процесуальну самостійність слідчого органу ДБР; функціональну самостійність органів і підрозділів ДБР у вирішенні тих питань, які віднесені до їхньої компетенції; надання їм права вносити пропозиції та рекомендації до вищестоящих підрозділів; забезпечення права працівників ДБР оскаржити дії та рішення безпосереднього керівника до вищестоящого керівника в установленому порядку тощо.

\section{Висновки}

Таким чином, підсумовуючи дослідження сутності та змісту основних принципів діяльності ДБР, ми можемо зробити висновок про їх недостатню нормативну урегульованість. Ст. 3 Закону лише в загальних рисах окреслює систему основних засад організації та діяльності ДБР і необхідною мірою не розкриває їх зміст та особливості реалізації. На нашу думку, такий підхід законодавця суттєво зменшує роль принципів в організації та діяльності ДБР і надає їм декларативного характеру.

\section{Список використаних джерел:}

1. Про Державне бюро розслідувань : Закон України від 12.112015 р. № 794-VIII. Відомості Верховної Ради України. 2016. № 6. Ст. 55.

2. Біденко О. В. Принципи діяльності Державного бюро розслідувань. Матеріали Міжнародної науково-практичної конферениї «Державне бюро розслідуванв: на шляху розбудови» (16 червня 2018 року, м. Одеса). Одеса: «Юридична література», 2018. С. $90-94$

3. Рішення Конституційного Суду України у справі за конституційним поданням Верховного Суду України щодо відповідності Конституції України положень ст. 69 Кримінального кодексу України від 2.11.2004 р. Офіщійний вісник України. 2004. № 45. Ст. 2975. 
4. Скакун О. Ф. Теорія держави і права : підручник / пер. 3 рос. Харків: Консум, 2006. $656 \mathrm{c}$.

5. Ожегов С. И., Шведова Н. Ю. Толковый словарь русского языка: 80000 слов и фразео- логических выражений. Москва : АЗЬ, 1995. $928 \mathrm{c}$.

6. Гаврилов Д. А. Правоприменительное толкование : дисс. ... канд. юрид. наук : 12.00.01. Волгоград, 2000. 235 с.

It is stated that the activity of the State Bureau of Investigation, like any other state body, should be carried out in strict accordance with certain principles, reflecting its purpose, influencing the definition of itstasks, goals and powers, is the basis for the formation of its system and structure. The content, the essence and the purpose of the principles of functioning of the State Bureau of Investigation, which reflect both the general theoretical views on a given legal category and the characteristic features of its work and organization, have been investigated. The role of the above principles in characterizing the administrative and legal status of this body is also determined. The peculiarities of legal recognition of the system of principles of State Bureau of Investigation in the current legislation, as well as the specifics of their manifestation in the law enforcement activity have been clarified. The essence and the content of such basic principles of organization and activity of State Bureau of Investigation as the rule of law, legality, justice, impartiality, independence and personal responsibility of each employee of State Investigation Bureau, clarity and transparency of the activity of the State Bureau of Investigation for society, accountability to the State bodies determined by law, political neutrality and non-partisanship, unity in exercising authority of the State Bureau of Investigation have been analyzed. The disadvantages of legal regulation of the basic principles of the State Bureau of Investigation activity have been identified, as well as the conclusion on the necessity of detailing the consolidation of their content has been made, since the legislator defines the system of basic principles of organization and activity of the State Bureau of Investigation only in general terms and does not reveal their content and peculiarities of implementation to the necessary extent.

Key words: rule of law, transparency, State Bureau of Investigation, unity, legitimacy, independence, impartiality, accountability, control, political neutrality, non-partisanship, principles, clarity, justice. 